\title{
The Effect Of Products, Promotion And Prices On The Interest Of Non Metal Trade In Pt Pegadaian Branch Help Mega Legend Batam
}

\author{
$1^{\text {st }}$ Yuliana Yuli \\ Business Administration Department \\ Politeknik Negeri Batam \\ Batam, Indonesia \\ yulianayuli08796@gmail.com
}

\author{
$2^{\text {nd }}$ Nur Rahmah Andayani* \\ Applied Business Administration Department \\ Politeknik Negeri Batam \\ Batam, Indonesia \\ nunun@polibatam.ac.id \\ *Corresponding author
}

\begin{abstract}
This research aims to determine and analyze the influence of products, promotions and prices on the interest in buying precious metal in PT Pegadaian Cabang Pembantu (CP) Mega Legenda Batam simultaneously or partially. The population in this study is 50 customers who repeatedly purchase precious metals from 2015-2017 at PT Pegadaian CP Mega Legenda Batam. The number of samples in this study were 50 respondents using non probability sampling method. The analysis method used in this research is descriptive analysis and multiple regression analysis using SPSS 20 program. The results of correlation analysis obtained $R$ number of $\mathbf{0 . 3 8 6}$. This shows that there is a strong relationship or correlation between product, promotion and price. The result of determination analysis $(38,6 \%)$ shows that the percentage of influence of independent variable to dependent variable is $38,6 \%$ while the rest of $61,4 \%$ is influenced or explained by other variable not included in this research model. This study conclude that product, promotion and price by partial and simultaneous result have positive and significant effect to interest to buy precious metal at PT Pegadaian CP Mega Legenda.
\end{abstract}

Keywords_ product, promotion, price and buying interest.

\section{INTRODUCTION}

\section{A. Background}

The borrowing and lending-based borrowing system in Indonesia has been going on for a long time, both formally and informally. Informally took place between individuals in society, formally starting with the establishment of State Pegadaian in 1901, now called PT Pegadaian (Persero). In its development Pawnshop has many meritorious and contribute great in fostering the welfare of the community. In addition, the role of pawnshops is also very necessary in order to encourage development activities.

In accordance with the definition of State Owned Enterprises (SOEs). According to Law Number 19 Year 2003 is a business entity that all customers or most of the capital is owned by the state through direct participation derived from separated state assets. SOEs are formed with the aim of meeting the needs of the broad audiences in the form of goods or services. As one of the state-owned companies, many pawn shops offer a variety of products, one of which is precious metal.

The precious metal products offered by PT Pegadaian (Persero) are in great demand by the people of Indonesia. The precious metal product is a gold bullion sale service to the community in cash or installment with easy process and flexible period of time. Precious metals can be an alternative safe investment option to realize the future needs, such as performing the pilgrimage, preparing the cost of education of children, have a dream home and private vehicles.

The Processing and Refining Business Unit (UBPP) Logam Mulia is one of the business units of PT Aneka Tambang (ANTAM) (Persero) Tbk. which engage in the processing and refining of precious metals such as gold, silver and platinum. UBPP Logam Mulia was founded in the 1930s by a Belgian gold trader named Rudolf Theodoor Braakensiek with a mobile location. Precious metals are metals that are resistant to corrosion or oxidation.

The product is the whole of the offer made normally by the company to the consumer in providing services, the location of the store and the name of the merchandise (18).

Promotion is a form of direct persuasion through the use of various incentives that can be set to stimulate the purchase of products immediately or increase the amount of goods purchased by customers (19).

Price is closely related to the basic value of consumer perception based on the overall element of the mix in creating a picture and experience of transacting, according to (18).

Buying interest is something derived from the learning process and thought process that forms a perception according to (2). Purchases made by consumers of a product will cause the desire to buy other products with different brands either 
because it is formed from the process of studying and observing the past.

Buying interest is something personal and related to attitudes. Individuals who are interested in an object will have the power or drive to conduct a series of behaviors to approach or acquire certain objects according to (10). PT Pegadaian (Persero) was originally a financial institution engaged in the provision of credit services to the community. Along with the development of the era and change of logo, PT Pegadaian (Persero) not only provide credit services with pawn system only but has penetrated into the business of selling Logam Mulia (LM) or gold bars certified.

PT Pegadaian Branch (CP) Batam is one of the branch offices of eight branch offices in the city of Batam. PT Pegadaian CP Mega Legenda Batam, built on 02 January 2014, not only serves pawn services, but also serves remittances in and out of the country, payment of electricity bills, water, provide borrowing of funds for customers with a procedure that is simpler than credit in the banking and also serve the purchase of precious metals.

Having precious metals is a long term investment and keeps the value of money so as not to be vulnerable to inflation. The high interest of investing in precious metals among the public, opens big opportunities for PT Pegadaian (Persero). So, in 2008 PT ANTAM (Persero) in cooperation with Perum Pegadaian which currently changed the status to become PT Pegadaian (Persero) sell the products of Precious Metals for Eternal Investment. The precious metal sold by PT Pegadaian (Persero) ranging from 1 gram, 5 grams, 10 grams, 25 grams, 50 grams and 100 grams.

In its development, the product of PT Pegadaian Mulia CP Mega Legenda Batam faced the challenge of sharia banking to the "akad" system used. Therefore, an alternative strategy is required by PT Pegadaian CP Mega Legenda Batam to strengthen the company's position in facing competition on Logam Mulia products. Strategy that is currently run by PT Pegadaian CP Mega Legenda Batam is by giving promotion in the form of print media. However, it is not optimal in its implementation, because the end result of the purchase of precious metals also did not increase the number of customers

\section{LITERATURE REVIEW}

\section{A. Products}

The product is defined as something that can be offered to a market to meet the needs or wants that can include: physical goods, services, experiences, events, people, places, organization, information, and ideas according to (11). Because the product of an organization / company can be seen and can also not look good in the form of goods or services.

The product is a visible, tangible and even tangible product designed to satisfy the wants or needs of the consumer (19). It means the goods are designed or made according to the needs of consumers.

\section{B. Product Life Cycle}

Basically the product life cycle consists of 4 phases/stages according to (11), namely:

1. Introduction phase

This phase is a period of slow adoption and participation rates when products (programs or services) are introduced in the marketplace. Where the cost is still effective high compared with the results (outcome).

2. Growth phase

This phase is marked by faster acceptance from the community so that it can improve the refund rate of promotion that has been issued.

3. The maturity / maturity phase At any given moment, the rate of growth will slow down and the product will enter a relatively mature phase.

4. Decrease phase For a program in this phase, sales are decreasing.

\section{Promotion}

Promotion is one of the variables in the marketing mix that is very important to be implemented by the company in marketing service products, according to (8). Promotional activities not only serve as a mean of communication between companies and consumers, but also as a tool to influence consumers in the purchase or use of services in accordance with the wishes and needs. This is done by using promotional tools such as brochures and advertisements. Promotion is often interpreted as persuasive communication and communication strategies include a habit of mixing / blending advertising, personal selling, sales promotion, public relations and direct marketing, according to (11). Introducing goods or services and then interpreting to the market or the wider community undertaken by a company is one form of direct promotion.

\section{Purpose of Promotion}

In detail the purpose of the promotion can be described as follows according to (19), namely:

a. Inform (informing)

b. Persuading targeted customers

c. Reminds (reminding)

The flow of goods or services from the manufacturer to the final sale.

\section{E. Price}

Price is a marketing tool used by an organization according to (11). Price is a very important tool as well as a factor influencing buyer decisions within the public sector and not tied to products

(goods / services). Simply put, prices can be interpreted as the amount of money (monetary unit) and / or other aspects (nonmonetary) containing certain use necessary to obtain a product, according to (19). Price can also be interpreted as the amount of money paid when doing transaction activities in the purchase of a product.

\section{F. Price Adjustment Strategy}

An alternative pricing strategy according to (19), as follows: 


\section{Discount}

Seen as the center of the entire product. The core product consists of the major needs that will be fulfilled by the wishes that will be realized and the problem to be solved by consuming this product.

2. The core product (the core product)

Seen as the center of the entire product. The core product consists of the major needs that will be fulfilled by the wishes that will be realized and the problem to be solved by consuming this product.

3. The actual product (the actual product)

More tangible and covering aspects such as product quality, features, packaging, style and design also include every brand name used. Ideally, every decision made is based on customer needs and references by considering alternative products (as more brands with different or almost identication qualities)

\section{G. Buying decision}

Purchasing decision is the final estuary of this research that has dimensions of attraction, steadiness, buying and as needed according to (5). Purchase decisions arise after consumers searching for more detailed information on a product by trying a product that ultimately leads to its own attraction so steady to buy a product as needed.

\section{$H$. Buying Interest}

Buying interest is the activities of individuals directly involved in obtaining and using goods and services including the process of decision-making on the preparation and determination of such activities according (1). Evaluation actions given to the quality of a product then processed into an information that aims to take into consideration in making purchasing decisions. Buying interest as a consumer's tendency to buy a brand or take action relating to a purchase measured by the level of likelihood of the consumer making a purchase according to (10). Purchases made by customers to benchmark the level of loyalty of a customer for the quality of service provided.

\section{Factors of Buy Interest}

Factors affecting buying interest are:

a. Differences in work, meaning that by the difference in one's work can be estimated interest in the level of work he wants to achieve, the activities undertaken, the use of his spare time, and others.

b. Socioeconomic differences, meaning that a person with a high socioeconomic nature will be easier to achieve what he wants than those with low socioeconomics.

c. Differences in hobbies or hobbies, meaning how one uses his spare time.

d. Differences in gender, meaning that the interests of women will be different from the interests of men for example in shopping patterns.

e. The age difference, meaning the age of children, adolescents, adults and parents will differ in interest to a good, the activity of objects and someone.

\section{Method}

\section{J. Design / Type of Research}

This research use explanatory research approach (explanatory research), that is research which explain causal relation (cause-effect) between research variables through a research question.

\section{K. Population and Sample}

The sampling method used is nonprobability sampling which does not provide equal opportunity for every element (member) of the population to be selected to be a member of the sample, using purposive sampling technique. Purposive sampling is a technique of determining the sample with certain considerations according to (14). The respondents selected in this study are 50 customers who repeatedly purchase precious metals, from 2015-2017.

\section{Validity and Realibility}

Validity test is used to measure the validity or validity of a questionnaire. Items that have a positive correlation with the criteria (total score) and high correlation, indicate that the item has a high validity as well according to (14).

Test Reliability is done to determine the level of consistency of measurement results if re-measured against symptoms and the same measuring instrument according to (17).

\section{DATA ANALYSIS METHOD}

The analytical methods used to analyze the data that has been collected are as follows:

\section{A. Descriptive Analysis}

Descriptive analysis is used to analyze the data that has been collected by way of describing or describing the object under study through the sample or population as is without doing analysis and make conclusions generally accepted according to (14).

\section{B. Classic Assumption Test}

To test whether the equation of the regression line obtained is linear and can be used for forecasting. The classical assumption test used in this research is data normality test, heteroscedasticity test, and multicolinearity test.

\section{Multiple linear regression analysis}

Multiple linear regression analysis is used when the researcher intends to predict how the rise and fall of the dependent variable if two or more independent variables (14).

\section{Hypothesis}

Hypothesis test used in this research is $t$ test (partial) and $F$ test (simultan). 


\section{RESULTS}

\section{A. Classic Assumption Test}

1. Data Normality

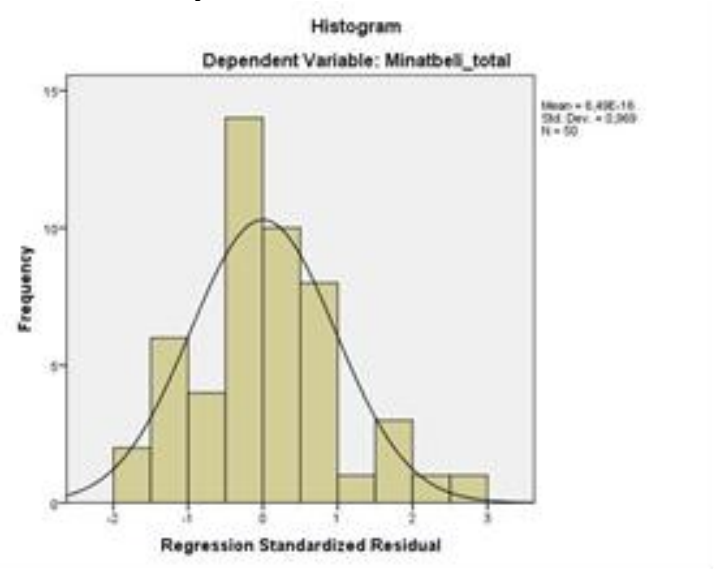

Fig. 1. Normality Test

Based on the picture above, it shows that the histogram mostly appears to follow the normal curve so it can be said the data is normally distributed because the data distribution (histogram) follows the normal curve pattern. Based on the Kolmogorov-Smirnov normality test results are obtained as concluded that the normality test using Kolmogorov-Smirnov is 0.708 with significance level of $0.697>0.05$ so it can be concluded that the residual is normally distributed.

2. Heteroscedasticity

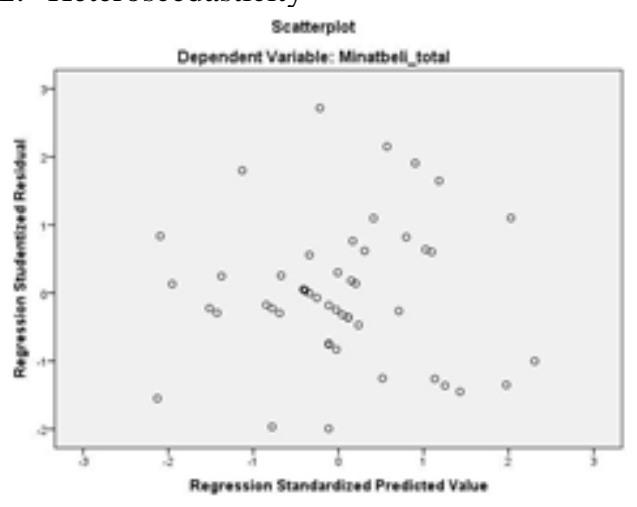

Fig. 2. Heteroscedasticity Test

Based on the image above heteroscedasticity test results In the scatterplot graph presented randomly spread spots do not form a clear pattern and spread both above and below the zero on the $\mathrm{Y}$ axis. This means there is no heteroscedasticity (happening homocedasticity) on the regression model.
3. Multicollinearity

TABLE II. MULTICOLLINEARITY TEST

\begin{tabular}{|c|c|c|}
\hline Variable & Tolerance & VIF \\
\hline Product & 0,873 & 1,145 \\
\hline Promotion & 0,786 & 1,272 \\
\hline Price & 0,741 & 1,349 \\
\hline
\end{tabular}

From the table above, it appears that no variable has a VIF value greater than 10 and a tolerance value smaller than $10 \%$, which means it can be concluded that there is no multicollinearity between independent variables in the regression model.

Based on the above table obtained the number (R square) of 0.386 or $(38.6 \%)$. according to the guidance table of instrument reliability interpretation in chapter 3 , the value shows at the interval coefficient of $0.20-0.40$ which means there is a low relationship between variables $\mathrm{X}$ to variable $\mathrm{Y}$.

\section{B. Multiple Regression Analysis}

1. The constant is 13,687: it means that if the product, promotion and price value is 0 , then the interest in buying the precious metal is fixed at 13.687.

2. The regression coefficient of product variable is 0,315 : it means that if other independent variables are fixed and the product value increases $1 \%$, then the buying interest will increaseby 0.315 .

3. The coefficient of promotion variable regression is 0,436: it means that if other independent variable is fixed and promotion value increase $1 \%$, then buying interest, will increase by 0,436 .

4. The regression coefficient of price variable is 0,170 : it means that if the other independent variable is fixed and the value of price increases $1 \%$, then the buying interest will increase by 0.170 .

\section{CONCLUSION}

From the results of research and discussion that has been done is the effect of product, promotion and price of interest to buy precious metals at PT Pegadaian CP Mega Legenda, the researchers draw the following conclusions:

1. Product variables partially have a positive and significant effect on interest in buying precious metals

2. Promotion variables partially have a positive and significant effect on the interest of buying precious metals

3. Price variable partially have a positive and significant effect on interest in buying precious metals 
4. Based on the results of the F test (simultaneous) there is a significant influence between product, promotion and price jointly to the interest of buying precious metals.

\section{REFERENCES}

[1] Ananda, Indra. (2016). Pengaruh Kualitas Pelayanan Terhadap Minat Konsumen Pada Ramayana Lestari Sentosa Pekanbaru. Jurnal FISIP, Vol.3 No.1

[2] Aptaguna, A dan Pitaloka, wwwwA. (2016). Pengaruh Kualitas Layanan dan Harga terhadap Minat Beli Jasa Gojek. Jurnal Manajemen, Vol.3 ISSN : 2337-7313.

[3] Dewi, Chandra (2014). Pengaruh Kualitas Pelayanan Terhadap Minat Beli Konsumen Di Rumah Makan Boga-Bogi Surakarta. Jurnal Informatika, Vol.1 No.2 ISSN 2337-5213

[4] Ghozali, Imam. (2012). Aplikasi Multivariate Dengan Program SPSS. Cetakan Keempat. Semarang: Penerbit Universitas Diponegoro.

[5] Haubl, GA. (2015). Review Pemasaran Internasional. Edisi Kedua. Jakarta: Prahalindo.

[6] Kotler, Philip dan Amstrong. (2013).Manajemen Pemasaran. Edisi Ketiga. Jakarta: Prahalindo.

[7] Lubis, Alfi Syahri. (2017). Pengaruh Kualitas Pelayanan (Service Quality) Terhadap Kepuasan Pelanggan PT. Sucofindo Batam. Jurnal Manajemen Bisnis.

[8] Lupiyoadi, Rambat dan A, Hamdani. (2014). Manajemen Pemasaran Jasa. Edisi 2. Jakarta: Salemba Empat..

[9] Y Malau, Harman. (2017). Manajemen Pemasaran :Teori dan Aplikasi Pemasaran Era Tradisional Sampai Era Modernisasi Global. Kesatu. Bandung: Alfabeta.
[10] Marini, Ita. (2015). Pengaruh Kualitas Pelayanan dan Harga Terhadap Keputusan Pembelian Wearpack Di PT Bukit Mas Batam. Skripsi, AB 053.

[11] Limakrisna, Nandan dan Susilo, Wilhelmus Hary. (2012). Manajemen Pemasaran: Teori dan Aplikasi Dalam Bisnis. Edisi Pertama. Jakarta: Mitra Wacana Media.

[12] Passe, Longginus. (2016). Pengaruh Kualitas Pelayanan Terhadap Kepuasan Nasabah pada PT. Bank Papua Cabang Daerah Istimewa Yogyakarta. Jurnal Ekonomi.

[13] Santoso, Singgih. (2012). Panduan Lengkap SPSS Versi 20. Jakarta: PT Elex Media Komputindo.

[14] Sugiyono. (2011). Metode Penelitian Administrasi. Cetakan Ke-19. Alfabeta, Bandung.

[15] ] Sugiyono (2014). Metode Penelitian Kuantitatif, Kualitatif dan $R \& D . \quad$ Cetakan Ke-20. Alfabeta, Bandung.

[16] Sunyoto, Danang. (2013). Metode dan Instrumen Penelittian. Cetakan Pertama. Yogyakarta: CPS.

[17] Supranto, J \& Limakrisna, Nandan. (2012). Petunjuk Praktis Penelitian Ilmiah Untuk Menyusun Skripsi, Tesis, dan Disertasi. Edisi 3. Jakarta: Mitra Wacana Media.

[18] Utami, Christina Whidya. (2014). Manajemen Ritel: Strategi dan Implementasi Operasional Bisnis Ritel Modern di Indonesia. Edisi 2. Jakarta: Salemba Empat.

[19] Widyaningrum, Nilam Ayu. (2017). Dampak Bauran Pemasaran Terhadap Minat Beli Konsumen Pada Produk Crispy Rice Crackers. Jurnal Manajemen dan Start-Up Bisnis, Vol.1 No 6. 